\title{
A EXPERIÊNCIA INTERIOR COMO EXPERIÊNCIA DE ATOR
}

THE INNER EXPERIENCE AS AN ACTOR'S EXPERIENCE

Christophe Bident

Universidade de Picardie

Amiens, França

Palavras-chave: Bataille; Stanislavski; experiência interior; dramatização; teatro; encenação; representação do ator.
Keywords: Bataille; Stanislavski; inner experience; dramatization; theatre; staging; acting.

Mots clés: Bataille; Stanislavski; expérience intérieure ; dramatisation ; théâtre ; jeu de l'acteur.

\section{Resumo}

Trata-se de voltar, com Georges Bataille, a um dos dramas mais excessivos e mais impossíveis de representar de $A$ formação do ator, de Stanislavski: a cena chamada de "o dinheiro queimado". Se Tortsov, o mestre desse ensaio teatral que assume a forma de uma narrativa de formação, não cessa de fazer seus jovens atores repetirem essa cena, ao ponto de ela tornar-se um dos leitmotiven maiores do livro, é porque Stanislavski vê nela um limite para o mimodrama e o melodrama cujo domínio é necessário à atuação moderna do ator. Essa cena age como um episódio crítico do acontecimento da "encenação". Pode-se lê-la como uma "experiência interior", o que permite precisar a um só tempo a filosofia singular de Stanislavski e o "método de dramatização" de Bataille.

\section{Abstract}

The objective here is to revisit, alongside with Georges Bataille, one of the most excessive, and most difficult to perform, dramas in Stanislavski's An Actor Prepares: the scene called "the burnt money". If Tortsov, the master in this theatrical essay that takes the form of a novel of formation, insists on asking his apprentices to repeat the scene, to the extent that it becomes one of the greatest leitmotiven in the book, it is because Stanislavski himself sees in it the outer frontiers of pantomime and melodrama, to which every modern actor should get acquainted to in order to act. This scene acts as a critical episode of the "staging" event. One could read it as an "inner experience",

\section{Résumé}

Il s'agit ici de revenir, avec Georges Bataille, sur l'un des drames les plus excessifs et les plus impossibles à représenter de La Formation de l'acteur, de Stanislavski: la scène dite de "l'argent brûlé". Si Tortsov, le maître de cet essai théâtral qui prend la forme d'un récit de formation, ne cesse de faire répéter cette scène à ses jeunes comédiens, au point qu'elle en devient l'un des leitmotivs majeurs du livre, c'est que Stanislavski voit en elle une limite au mimodrame et au mélodrame dont la maîtrise est nécessaire au jeu moderne de l'acteur. Cette scène agit comme un épisode critique de l'avènement de la "mise en scène". On peut la lire comme une "expérience intérieure", ce qui 
which allows for a double particularization: that of Stanislavski's singular philosophy and that of Bataille's "dramatization method". permet de préciser à la fois la philosophie singulière de Stanislavski et la "méthode de dramatisation" de Bataille.

A história se passa aqui, neste apartamento. Maria é a mulher de Kostia, que é tesoureiro de uma repartiçấo qualquer. Eles têm um bebê adorável, em quem a mãe dela está dando banho no cômodo ao lado. Durante esse tempo, o marido examina papéis e faz suas contas. Não é dinheiro seu, mas da repartição, que ele acabou de trazer do banco. Uma pilha de maços de notas se encontra sobre a mesa. O irmão de Maria, Vania, alguém de espírito simples, está de pé na frente de Kostia e o observa arrancar as fitas coloridas que unem os maços de notas e jogá-las ao fogo.

Kostia acabou de contar todo o dinheiro. Maria o chama para ver o bebê no banho. Deixado sozinho, o irmão, na sua inocência, querendo imitar Kostia, joga alguns papeis no fogo; depois, achando que maços inteiros queimam ainda melhor, delirando de prazer, joga tudo no fogo - todo aquele dinheiro que o tesoureiro pessoalmente acabara de retirar do banco. Bem nesse momento, Kostia volta para ver o último maço de notas inflamar-se. Fora de si, ele se lança sobre a lareira e empurra o idiota que cai gemendo, depois, soltando um grito de raiva, retira do fogo o último maço meio carbonizado.

Assustada, sua mulher corre e vê o irmão estendido no chão. Ela tenta levantá-lo, mas não consegue. Vendo sangue em suas mãos, grita a seu marido para ir pegar água, mas como ele náo ouve nada e não se mexe, ela mesma vai. Ouve-se um grito agudo vindo do cômodo ao lado. O bebê está morto, afogado no banho.

Assim é uma das narrativas que Tortsov, o mestre de $A$ formação do ator, pede a seus alunos para improvisar e que ele nomeia, através de uma metonímia delicada, "a cena do dinheiro queimado".* Stanislavski a qualifica também como "trágica" e fala dela como de

* (STANISLAVSKI, Constantin. La formation de l'acteur. Paris: Payot, 2001: 80.) um "melodrama". Com efeito, nada mais horrível, e se o exercício é repetido várias vezes ao longo desse romance de formação de um novo exercício do ator, é porque a questão que ele coloca é primeiramente a questão de sua possibilidade. Como representar essa cena, essa cena-limite, de maneira crível e verdadeira? Essa cena é em si representável? E é precisamente, suspeitamos, porque ela não o é ${ }^{1}$

\footnotetext{
${ }^{1}$ Tortsov diz mais adiante: "Eu não dei a vocês essa cena para representar porque achava que vocês poderiam representá-la. Propondo a vocês de trabalhar para além de suas forças, eu quero somente fazê-los tomar consciência de seus defeitos e mostrar-lhes em que sentido será preciso trabalhar" (STANISLAVSKI, Constantin. La formation de l'acteur, op. cit.: 143).
} 
que será recolocada no trabalho, como um objetivo ideal e impossível de se atingir, mas que permite tirar a medida da desmesura à qual a ambição do ator pode compelir.

Ora, Stanislavski inscreve essa questão da representatividade, ou da representabilidade, entre dois parâmetros, que são justamente o drama e a cena. O exercício abre o quinto capítulo do livro, que trata da "concentraçáa". Pela primeira vez, os atores-aprendizes deixam o famoso "salăo de Maria", onde podiam construir suas improvisaçóes de maneira naturalista, sem se preocuparem com um público eventual, entre quatro paredes. A nova narrativa é proposta a eles no mesmo dia em que Tortsov levanta a cortina, abrindo assim a quarta parede "para o enorme buraco negro do proscênio". Kostia, o narrador, admite: "Essa mudança desorientou a todos nós". É então no mesmo dia em que desorienta os atores de um salão na direção de uma cena que Tortsov lhes dá o exercício mais dramático que já lhes tinha dado. É exatamente a questão que ele coloca no final da primeira narração da cena: "É bastante dramático para fazer vocês se esquecerem da presença do público?” Como se um excesso de drama tornasse a cena necessariamente obs-cena, como se esse ápice do melodrama devesse literalmente ob-cecar os atores e circunscrever seus movimentos. A existência de uma cena reencontra assim sua verdadeira motivação: fornecer o lugar de uma concentração do drama.

O exercício é então apresentado aos alunos para lhes permitir utilizar conjuntamente os recursos do melodrama e os da quarta parede. Ele responde a um duplo objetivo: esgotar o melodrama, autonomizar a cena.

É claro que a questão dos limites da representação não é nova no teatro. Dependendo dos lugares e das épocas, a encenação respondeu à imaginação excessiva dos escritores através de convençôes, mímicas ou narrativas. Mais adiante em $A$ formação do ator, Stanislavski ecoa isso ao remeter às "ondas invisíveis" que circulam entre Hamlet e Ofélia, à "comunicação silenciosa” entre eles, à "comunicação interior" deles. Tortsov fala sobre isso a seus alunos como de uma alegoria do comunicável ou do incomunicável teatral: "A dificuldade, aqui, é que tenho que falar com vocês de uma coisa que percebo intuitivamente, mas que não conheço. É impossível explicá-lo a vocês através de palavras". Como dizer o inefável, fazer aparecer o segredo, tornar visível o invisível, reconhecível o que o é com dificuldade: esta série de reconhecimentos críticos, que acen- 
tuam a cada vez a aspereza do problema, é a questão do teatro, do teatro de Stanislavski. Ele recorre a um vocabulário de transcendência, ao ter consciência da sua imperfeição: batiza essa experiência como um "fenômeno de irradiação".*

É esse vocabulário de transcendência que Brecht recusa quando evoca a ambição "megalomaníaca" de Stanislavski. À pretensão do ator, que pretende "poder representar qualquer ação imaginável, ainda que fosse a mais improvável de todas", Brecht opóe a mudança de paradigma própria da modernidade e, particularmente, da modernidade marxista: as experiências extremas não dependem da fatalidade, mas de determinismos econômicos e sociais. Evocando uma peça de Hauptmann, ele mostra que a questão do aborto não depende mais, desde então, unicamente da lei religiosa, mas do contexto socioeconômico no qual é recomendável, ou não, educar uma criança. $\mathrm{O}$ exemplo que ele escolheu me interessa também porque reúne, no seu modo extremo, a narrativa de Tortsov: a morte do feto em um, a morte do bebê no outro.*

Ora, essa questão que parece ser a mais própria do teatro e que os debates naturalistas, expressionistas e marxistas renovam com força, é também, de maneira mais geral, uma questão estética ou poética: a questão da transmissibilidade da experiência. É ao menos nesses termos que Georges Bataille coloca a questão da poesia em A experiência interior. $\mathrm{Ou}$, antes, é assim que ele coloca a poesia em questão e que ele avança a necessidade de uma "dramatização".

A experiência interior é um livro publicado em 1943 e que tenta ir mais longe que as místicas, os escritores e os fenomenólogos reunidos no caminho do reconhecimento do que é realmente, profundamente, excessivamente, uma experiência para um sujeito.

Eis aqui, rapidamente, uma das definiçóes da experiência pelas quais Bataille começa seu livro: "A experiência é colocar em questão (à prova), na febre e na angústia, o que um homem sabe do fato de ser”. Essa seria uma definição suficientemente boa da experiência dos atores que têm que representar, ou reviver, ou experimentar, de acordo com os termos de Stanislavski (e de acordo com a tradução proposta por Jean-Pierre Thibaudat e Macha Zonina para as Notas artísticas), ${ }^{2}$ a cena do "dinheiro queimado". Substituamos a palavra "homem" pela palavra "ator", acrescentemos à "experiência" o epíteto "teatral", e a frase torna-se totalmente stanislavskiana: a expe-

${ }^{2}$ Cf. STANISLAVSKI, Constantin. Notes artistiques. Belval: Circé, 1997: 10. Essa edição reúne textos de Stanislavski em sua maioria dos anos 1907 a 1913.
* (STANISLAVSKI, Constantin. La formation de l'acteur, op. cit.: 211-212.)

* (Cf. BRECHT, Bertolt. L'achat du cuivre. Tradução de André Combes e Bernard Lortholory. Paris: L'Arche, 1999: 98 e 114.) 
* (BATAILle, Georges. L'Expérience intérieure. Paris: Gallimard, 1943/1954: 19.)

* (STANISLAVSKI, Constantin. La formation de l'acteur, op. cit.: 168.) riência teatral é colocar em questão (à prova), na febre e na angústia, o que um ator sabe do fato de ser. Parodiemos ainda esta outra definição: "Eu chamo de experiência uma viagem ao fim do possível do homem".* Ela se tornaria: Eu chamo de experiência teatral uma viagem ao fim do possivel do ator.

Uma vez vivida, essa experiência extrema é transmissível? Esse é o ponto de combustấo da questão de Bataille. Essa experiência interior, íntima, secreta, extática, erótica, mística ou sacrificial, essa experiência interior que, paradoxalmente, é a experiência de uma saída de si, ou até de uma perda de si, essa experiência que Bataille nomeia também como soberana, vivida na intensidade imediata do instante, é transmissível a outra pessoa, é relatável em um outro tempo, em uma outra cena, é representável em uma outra linguagem? Relatá-la, não é necessariamente transformá-la, empobrecê -la, traí-la, ser-lhe infiel? Ora, todas essas questóes são também as de Stanislavski: como fazer de modo que a representação da experiência mais viva permaneça a experiência mais viva, como fazer dela uma recriação e não uma recreação, como concebê-la, de um ponto de vista a um só tempo orgânico e racional, sem reduzi-la a uma mecanização artificial?

Sei bem tudo o que, por outro lado, poderia opor Bataille a Stanislavski. Mas tanto para um como para o outro a experiência interior é fundadora. Tortsov anuncia em $A$ formação do ator: "A experiência interior vem em primeiro, depois ela se veste com uma forma exterior"; "toda demonstração exterior é convencional e sem interesse se ela não tem uma razão interior"; "é a sua própria vida interior, adaptada ao seu próprio papel, que deve inspirar a peça”.* Ele o diz novamente em A construção do personagem: "Sópode haver arte em um papel se dele se fizer a experiência real'. Para Stanislavski, assim como para Bataille, é necessário um método, um método de dramatização. Eu gostaria aqui de mostrar, em relação a três pontos, as semelhanças fecundas entre esses dois métodos: elas passam pela contestação da forma, pela sacralização do espaço e pela colocaçẫo em jogo do excesso.

\section{A contestação da forma}

Volto a Bataille, ao primeiro movimento de seu pensamento: nenhuma transmissão, nenhuma representação de uma experiência dos limites saberia encontrar repouso em uma forma. Isso seria trair 
o instante, a sensação, a imediatez, a presença, o fogo da experiência. Ora, esse é o segundo movimento, a experiência também não saberia existir, existir para um outro, sem uma forma de transmissão e de representação. A experiência só pode existir para ser relatada. É preciso então encontrar uma forma que leve em conta sua inadaptação fundamental, sua própria impossibilidade, sua própria incapacidade de transmitir o todo da experiência. É preciso encontrar uma forma que se conteste a si mesma, que conteste sua própria existência e sua própria autoridade, que conteste sua própria legitimidade e que, porque ela a contesta, faça do sujeito legítimo, legitimado, uma autoridade, um autor, um criador.

Ora, é precisamente disso que Stanislavski tem consciência: a encenação não pode acontecer sem essa forma segunda que o ator deve encontrar em sua experiência do drama, pelo método ou pelos métodos segundo os quais ele vai reviver a experiência do drama. É preciso reviver, reexperimentar o papel, o que é a um só tempo vivê-lo e repeti-lo, o que requer ao mesmo tempo percepção e concepção, imanência e transcendência, sensibilidade e método, imediatidade e diferença. $\mathrm{O}$ ator só pode dar a sensação do vivo através de meios técnicos, psíquicos e físicos. Stanislavski afasta assim qualquer mitologia da inspiração, da experimentação pura, da autenticidade imediata: a verdade do papel depende sempre de um segundo grau. Daí as formulações contraditórias do capítulo de $A$ formação do ator sobre a sinceridade e a verdade. A verdade artística é inseparável de uma forma de mentira.

De um lado, a intimação de Tortsov é clara: "Abordem sempre uma peça pelo interior”.

O que conta, para nós, é a existência real da vida interior de um ser humano em um papel e a fé nessa realidade. [...] O que se chama de verdade, no teatro, é a verdade da cena [...]. A verdade no palco é tudo aquilo em que o ator pode acreditar com sinceridade, tanto nele mesmo como em seus parceiros. A verdade náo pode ser separada da fé nem a $f e ́$ da verdade. Elas não podem existir uma sem a outra e, sem elas, o ator é incapaz de viver seu papel e de criar. Tudo o que acontece no palco, a cada instante, deve poder convencer tanto o ator quanto seus parceiros, assim como o público. Ele deve fazê-los acreditar na possibilidade na vida real de sentimentos análogos àqueles que ele experimenta em cena.*

Mas é para acrescentar, por outro lado e rapidamente: "Certos atores, como vocês, são de tal modo rígidos consigo mesmos que levam frequentemente, sem se darem conta, o amor que têm

* (STANISLAVSKI, Constantin. La formation de l'acteur, op. cit.: 137. Ver também STANISLAVSKI, Constantin. Notes artistiques, op. cit.: 221.) 
* (STANISLAVSKI, Constantin. La formation de l'acteur, op. cit.: 138.)

* (Ibidem: 164.)

* (Ibidem: 150.)

* (Ibidem: 153.)

* (Ibidem: 154.)

* (Ibidem: 158.)

* (BATAILLE, Georges. L'Expérience intérieure. Paris: Gallimard, 1943/1954: 136.)

* (STANISLAVSKI, Constantin. Notes artistiques, op. cit.: 113.)

* (STANISLAVSKI, Constantin. La formation de l'acteur, op. cit.: 67.) pela verdade a um extremo que equivale à mentira. Não exagerem o amor que vocês têm pela verdade nem a aversão que têm pela mentira, pois isso conduzirá vocês a representar a verdade por si mesma, e isso é, por si, a pior das mentiras". * Daí esta feliz fórmula, na conclusão do capítulo: "É da verdade transformada pela imaginação criadora em um equivalente poético que precisamos".* Viver, experimentar é, portanto, transformar: o objeto do jogo, o equivalente poético, é uma transformação da verdade. Trata-se, assim, de "dar uma alma" ao personagem, ou seja, sua "linha de comportamento", ${ }^{*}$ que permita restituir sua "vida subconsciente", ${ }^{*}$ através de "açôes físicas" adaptadas,* sempre mais simples de se definir que as ações psicológicas, pois "(os sentimentos) são inapreensíveis e escorregam por entre os dedos como gotas d'água”.*

Essa forma é, para Bataille, a forma poética (em um sentido que lhe permite incluir tanto Nietzsche e Proust quanto Rimbaud ou Mallarmé), porque a linguagem poética é precisamente aquela que se contesta como linguagem. A experiência assim só existe para ser alterada em uma forma que trabalhe sobre si mesma e que trabalhe assim para se alterar. Esse trabalho da forma poética sobre si mesma demanda, diz Bataille, um "método", um método de "dramatização": "A experiência restaria inacessível se não soubéssemos dramatizar".*

Ora, aqui estão as palavras de Stanislavski: um método, um método de dramatização, um "trabalho do ator sobre si mesmo" (é esse, sabe-se, o verdadeiro título do livro completo, que agrupa $A$ formação do ator e $A$ construção do personagem). A uma poesia que passa pela raiva da poesia, como o dirá Bataille, responde um teatro que passa pela aversão ao teatro, como havia dito Stanislavski: "No teatro, eu detesto o teatro". ${ }^{*}$ Esse trabalho dialético é a condição prévia para refundação tanto do ato poético quanto do ato teatral.

Em Stanislavski, é o se mágico que dá à experiência sua autoridade: a criação interior de um mundo passa pela integração e pela transformação do mundo exterior no mundo imaginário da experiência e ela permite a revelação, a manifestação desse mundo transformado.* Essa exigência supóe não recuar frente a nenhuma manifestação do mundo, seja ela horrível ou, como dirá Bataille, informe (o informe, precisamente: um questionamento excessivo da forma). Imagina-se Bataille vibrando com a leitura dessa passagem em que Tortsov leva a doutrina naturalista a seus limites: 
Nada é mais belo que a natureza. Ela deve ser o objeto de uma contínua observação. Peguem, para começar, uma simples florzinha, ou entáo uma de suas pétalas, uma teia de aranha, ou um desenho de geada sobre uma vidraça, e tentem explicar através de palavras por que vocês gostam desses objetos. $\mathrm{O}$ esforço que vocês terão que fazer forçará vocês a observá-los mais atentamente e mais exatamente para melhor defini-los. E não fujam da natureza em seu aspecto mais obscuro. Procurem-no nos pântanos, na lama, na escória, e lembrem-se que, por trás desses fenômenos, se esconde a beleza. A beleza verdadeira não teme ser desfigurada. Pelo contrário, até mesmo a desfiguração frequentemente só acentua a beleza e a coloca em evidência.*

Poder-se-ia citar também a passagem das Notas artísticas em que Stanislavski evoca a coragem com a qual "os gênios russos", como Tolstoi e Dostoievski, analisam a essência da natureza humana: "tudo se passa como se, arregaçando as mangas, eles se introduzissem sem desgosto algum na alma humana, a revirassem com crueldade ou obstinação, centímetro por centímetro, e tirassem dela o pus".*

É por isso que o ator não pode recuar diante da necessidade de representar o excesso do melodrama, a experiência-limite proposta pela cena do dinheiro queimado. Acontece também de Bataille citar cenas prosaicas, cenas do mundo, cenas que não dependem nem de sua própria experiência nem da experiência da literatura: são, em Bataille, cenas de faits divers. Há uma que particularmente vale a pena ser citada aqui:

Cito agora, de memória, uma notícia publicada no Jornal há uns quinze anos (cito-a de memória, mas náo acrescento nada): em uma cidadezinha ou talvez um vilarejo da França, um pobre operário ao fim de uma semana volta para casa trazendo seu pagamento em notas. Um menino de alguns anos vê as notas, brinca com elas e as joga no fogo. Percebendo tarde demais, o pai perde a cabeça, pega um machado e, no desvario, arranca as duas mãos do menino. A mãe dava banho na filha no cômodo ao lado. Ela entra, atraída pelos gritos, e cai morta. A menina, no banho, se afoga. Ficando subitamente louco, o pai fugiu, errando pelos campos.*

E quando reedita o livro, onze anos após a primeira publicação, Bataille traz algumas modificações, mas se preocupa em acrescentar a seguinte nota:

Tenho que aproximar dessa passagem, publicada na primeira ediçáo (1943), a seguinte notícia publicada no Ce soir em 30 de setembro de 1947: "Praga, 29 de setembro. - Um drama chocante acabou de
* (STANISLAVSKI, Constantin. La formation de l'acteur, op. cit.: 99-100.)

* (STANISLAVSKI, Constantin. Notes artistiques, op. cit.: 207-208.)

* (BATAILLE, Georges. L'Expérience intérieure, op. cit.: 141.) 
ocorrer no domicílio de um açougueiro de Chomutov. O comerciante contava seus lucros do dia... quando teve que se ausentar por um instante. Seu filho, de cinco anos, para brincar, ateou fogo nas notas. A mulher do açougueiro, ocupada em dar banho no seu outro filho, de um ano, não pôde intervir, mas os gritos dela alertaram o pai que [...] pegou seu cutelo e cortou o pulso da criança. Com esse espetáculo, a mãe sucumbiu, morta por uma embolia e o bebê a quem ela dava banho se afogou na banheira. O açougueiro fugiu." Aparentemente, simples retomada de um tema perfeito, sem interesse no meu ponto de vista. Eu devia, entretanto, mencionar o fato. ${ }^{3 *}$

\section{A sacralização do espaço}

Em $A$ experiência interior, essa dupla cena, que será também designada como a do dinheiro queimado, acontece em um conjunto sobre "o êxtase frente ao objeto" e, mais precisamente, em uma sequência de fragmentos sobre o misticismo, a religião e o sacrifício. Acabaram assim de ser evocados os nomes de Teresa d'Ávila, Heloísa, Isolda, Inácio de Loyola.

Ora, é preciso lembrar a dimensão sagrada, se não sacrificial, da narrativa de formação que é o díptico que compóe $O$ trabalho do ator sobre si mesmo. Como qualquer narrativa de formação, ela impóe ao personagem principal, modelo do ator futuro, uma série de provas, de restriçóes, de sacrifícios, em nome daquilo que Tortsov acaba por chamar, no final do segundo tomo, de "a ética teatral”. Ao ator é solicitado ensaiar em casa assiduamente, observar

\footnotetext{
${ }^{3}$ Trata-se realmente de uma notícia? Consultei o jornal Ce soir de 30 de setembro de 1947 sem encontrar esse resumo, que não aparece mais nos exemplares dos dias anteriores nem posteriores. O que pensar? Bataille tinha também uma formação de arquivista e não irei questionar sua referência. Pode-se também supor que havia a cada noite várias ediçóes desse jornal popular de quatro páginas, dirigido por Aragon, e que Bataille tivesse em mãos uma edição diferente daquela que foi conservada pela Biblioteca Nacional da França. Pois o Ce soir publica cotidianamente um número de notícias da mesma natureza. Julguemos por alguns títulos: "O gigante nu aterroriza um bairro de Londres" (30 de agosto), "Atira em uma lebre e mata a mulher" (19 de setembro), "Octogenário golpeia a mulher com um penico" ( $1^{\circ}$ de outubro). E no dia 30 de setembro, dia mencionado por Bataille, lê-se a seguinte notícia, menos edificante mas em parte comparável com a nossa... "Nice, 29 de setembro. Uma violenta briga aconteceu ontem às $22 \mathrm{~h}$, na avenida Primerose, em Nice, entre o Sr. Pierre Cristini e sua esposa. A Sra. Cristini, cansada, foi para seu quarto e bebeu nitrobenzeno. Um dos filhos, Zéfiro, partiu para cima de seu pai e o ameaçou com um revólver: - Você é um pai desprezível, gritou ele, vou te matar. O Sr. Cristini saiu correndo desesperadamente, mas não se sabe mais o que se sucedeu a ele desde então. Quanto à infeliz mulher, ela morreu chegando ao Hospital Pasteur, ontem às 22h 50".
} 
diariamente o século e atuar em cena todas as noites: ele entra a serviço de uma estética sacra. Nessa preocupação de edificação, Stanislavski mistura as referências gregas e cristãs: "O ator deve sentir o limiar e a proximidade da cena. Desde a infância somos fascinados pelo altar e pelas Portas Reais. Não se pode atravessá-las sem um certo medo. Essa sensação deveria ser sentida pelo ator quando entra em cena".* Stanislasvki reivindica "atores-sacerdotes" para um "teatro-templo".*

A sacralização do espaço tem, assim, apenas um objetivo: favorecer a performance do ator e, desse modo, a atenção e a edificaçáo do público. A decoração, a iluminação, a sonoplastia, por exemplo, não servem a objetivos espetaculares: a função delas, em Stanislavski, é "facilitar o trabalho de concentração do ator em cena", permitindo-lhe "sentir seu papel muito mais intensamente".*

Lembro que, em $A$ formação do ator, a primeira ocorrência da cena do dinheiro queimado aparece no início do capítulo sobre a concentração. É o primeiro exercício dado aos atores com a cortina levantada. Tortsov, assim, chama a atenção dos atores desorientados para a tendência deles a se preocuparem com a sala em detrimento do que estão representando.* É o princípio: "Para desviar a atenção da sala, é preciso que vocês se interessem por alguma coisa no palco".* Esse "alguma coisa" pode ser um ponto fixo, como aquele aluno a quem Souler pede que olhe para um único ponto a fim de ativar a imaginação.* Pode ser também o que Stanislavski chama de diferentes círculos ou campos de atenção (pequeno, médio e grande). Começar pelo trabalho sobre o pequeno campo de atenção é um refúgio para a concentração.* Estender pouco a pouco o diâmetro dos círculos permite colocar à prova, cada vez mais, essa faculdade de concentração.

Ora, em Bataille, a dupla cena do dinheiro queimado é precisamente seguida por um fragmento sobre a necessidade da concentração para manter a qualidade da experiência interior:

Fixo um ponto à minha frente e represento esse ponto como o lugar geométrico de toda existência e de toda unidade, de toda separação e de toda angústia, de todo desejo insaciado e de toda morte possíveis. Prendo-me a esse ponto e um profundo amor do que está nesse ponto me queima até recusar estar em vida por outra coisa que náo o que está ali, por esse ponto que, sendo junto vida e morte de um ser amado, tem uma cintilaçáo de catarata.*
* (STANISLAVSKI, Constantin. Notes artistiques, op. cit.: 74.)

* (Ibidem: 146-147.)

* (STANISLAVSKI, Constantin. La formation de l'acteur, op. cit.: 183 e 186.)

* (Ibidem: 84.)

* (Ibidem: 82.)

* (STANISLAVSKI, Constantin. Notes artistiques, op. cit.: 140.)

* (STANISLAVSKI, Constantin. La formation de l'acteur, op. cit.: 91.$)$

* (BATAIlle, Georges. L'Expérience intérieure, op. cit.: 141.) 
A carga afetiva que Bataille atribui à experiência pode parecer excessiva para Stanislavski, pelo menos em sua formulação. Entretanto, trata-se, em um e outro, de pôr em jogo faculdades insuspeitadas que permitem lançar um outro olhar sobre a singularidade do sujeito.

\section{A colocação em jogo do excesso}

Passemos, de fato, em Stanislavski, à segunda ocorrência da cena do dinheiro queimado. Ela aparece logo após a primeira, no início, mais uma vez, do capítulo seguinte, que trata do relaxamento. Ela age nesse caso como um acontecimento raro e mesmo único da narrativa: sob o efeito de uma tensão extrema, de uma crispaçấo excessiva, Kostia abre uma artéria, desmaia e vai para o hospital. Acontecimento surpreendente, para não dizer inesperado, diabolicamente batailliano. Stanislavski não recua diante do excesso do drama e da descrição:

Entrando na sala, o Diretor me chamou com Maria e Vania e nos pediu para fazer a cena do dinheiro.

No início, tudo ia bem. Mas quando chegamos ao momento dramático da cena, senti em mim alguma coisa que hesitava. Procurando me controlar, peguei e apertei com todas as minhas forças o primeiro objeto que caiu na minha mão. De repente, me pareceu que alguma coisa estava se quebrando e, no mesmo instante, senti uma dor aguda e como se um líquido quente inundasse minha mão. Em seguida, eu não sei o que aconteceu. Perdi a consciência.

Eu tinha cortado uma artéria e tinha perdido tanto sangue que tive que ficar de cama vários dias. Esse infeliz acidente levou o Diretor a fazer uma mudança no programa e a começar mais cedo que o previsto uma parte da nossa preparaçáo física.*

(STANISLAVSKI, Constantin. La formation de l'acteur, op. cit.: 103.)

Assim, uma experiência excessiva fracassa em representar outra experiência excessiva. Stanislavski procura, assim, mostrar a necessidade de um método e, nesse caso, de uma parte integrante do método, do "relaxamento muscular" obtido pelo relaxamento. Trata-se aqui de distinguir entre a experiência inconsciente (não preparada, imediata, selvagem) que leva ao torpor, à perda de consciência, à hemorragia e à hospitalização, e a experiência sincera, que pressupóe um relaxamento muscular e nervoso, susceptível de prevenir qualquer tensão dos gestos e qualquer fixação das imagens. ${ }^{*}$ $\mathrm{Na}$ construção metódica da narrativa, o capítulo sobre a concentraçâo havia seguido aquele sobre a imaginação, pois se trata de mos- 
trar que a concentração permite reconduzir a uma justa medida um excesso de imaginação. Trata-se agora de mostrar que o relaxamento age como uma barreira ao excesso possível de concentraçáo que, em Kostia, desemboca em uma histericização perigosa. Colocar em risco uma emoção excessiva, em Stanislavski, volta sempre a medir o quantum de afeto, para falar com Freud, e a escolher sua forma, representando-o.

Será assim ainda quando, em um capítulo posterior, a cena do dinheiro queimado voltar pela terceira vez. Kostia ainda não chega a encontrar o "sentido da medida".* É preciso que Tortsov realmente coloque fogo em um papel para que Kostia se precipite naturalmente para ir apagá-lo, mais uma vez, não sem perigo: "eu me precipitei com tal violência que quase quebrei um braço de Vania”.*Trata-se agora, para Stanislavski, de mostrar a necessidade de definir uma linha de ações físicas. Essa linha de ações físicas vai permitir encontrar o justo compromisso entre o risco de histericização e a consciência da semelhança necessária à representação. Nessa mesma passagem, Tortsov lembra aquela anedota da mulher a quem teve que anunciar a morte do marido: durante dez minutos, ela ficou imóvel, depois, subitamente, desmaiou. Aqui está o gênero de ação física a ser evitado: completamente verdadeira e sincera, mas de parte a parte histericizada, ela é irrepresentável nos palcos. Encontrar a ação física ao mesmo tempo mais justa e mais adequada à representação, esse é então o objeto do "trabalho do ator sobre si mesmo": trata-se de conceder o lugar apropriado a uma forma de excesso.

Percebe-se, assim, o papel primordial que Stanislasvki concede ao momento histérico da construção do personagem. Ele o dirá novamente na segunda parte do "trabalho do ator". O método pede ao ator que experimente a experiência e a coloque à distância para poder dar-lhe forma:

Nossa arte exige que um ator experimente as angústias de seu papel, que ele chore todas as lágrimas de seu corpo em casa ou durante os ensaios, de modo a atingir a calma, de modo a se livrar de todos os sentimentos estranhos ao seu papel ou que possam prejudicá-lo. Ele pode, então, aparecer em cena para comunicar ao público as angústias pelas quais passou, mas em termos claros, cativantes, profundamente sentidos, inteligíveis e eloquentes.*

É em tais experiências iniciais que Bataille vê "a existência se desnuda(r) sucessivamente de seus meio termos".* "O ser nos é

* (STANISLAVSKI, Constantin. La Construction du personnage, op. cit.: 95.)

* (BATAILLE, Georges. L'Expérience intérieure, op. cit.: 135.) 
* (BATAILLE, Georges. Madame Edwarda. Collection 10/18. Paris: Pauvert, 1956: 16.$)$

* (BATAILle, Georges. L'Expérience intérieure, op. cit.: 21.)

* (STANISLAVSKI, Constantin. La formation de l'acteur, op. cit.: 168.)

* (Ibidem: 169.) dado em uma ultrapassagem intolerável do ser, não menos intolerável que a morte”, lê-se no prefácio a Madame Edwarda.* É essa ultrapassagem intolerável, insuportável que Stanislavski representa na experiência de Kostia. Poder-se-ia mesmo dizer que é a razão de ser da narrativa bicéfala que ele constrói: dar a narração a Kostia, que carrega seu nome, volta a dramatizar e a sacralizar a narrativa, pois Kostia é de todos os atores estudantes aquele que investe mais, pronto para tentar e sacrificar tudo para tornar-se Tortsov. Kostia é o personagem que se encarrega do excesso de uma narrativa cuja finalidade consistirá em dar a medida justa à desmesura própria a todo excesso.

Se, então, "é preciso", como escreve Bataille, "viver a experiência", e vivê-la "até o transe", não se deve deixar de implementar todos os procedimentos conscientes do método para dar a perceber as formas extremas da prova. É aqui que os métodos de Bataille e de Stanislavski divergem, e é por isso que o alicerce filosófico do método de Stanislavski deveria ser procurado menos do lado de Bataille do que nos fenomenólogos que este acreditava ultrapassar (e em particular, talvez, de Merleau-Ponty). A relação entre a intenção e o gesto pode ser lida nos mesmos termos de uma fenomenologia da percepção. A intençấo do ator resulta da construção de uma representação mental. Essa representação mental pode, e mesmo deve, levar em conta a totalidade de um gesto. Os gestos do ator não devem saber mais sobre ele do que ele sabe sobre seus gestos. $\mathrm{O}$ ator pode e deve poder dar conta de suas intençôes quando faz esse ou aquele gesto.

Nesse contexto, compreende-se porque o recurso à "memória afetiva" é fundamental. Stanislavski pede ao ator que adapte sua vida interior ao personagem, para recobrir incessantemente "a experiência interior" com uma "forma exterior".* Isso pede que se renove a experiência interior, dando-lhe a cada vez a forma exterior apropriada: para isso, o ator precisa saber mobilizar uma memória afetiva profunda.* $\mathrm{O}$ ator se serve de suas próprias cenas afetivas para construir, por analogia, as do personagem.

Stanislavski multiplica uma vez mais os exemplos e a analogia torna-se uma regra. ${ }^{4}$ Uma regra da qual ele dará, que eu saiba,

\footnotetext{
${ }^{4} \mathrm{~A}$ analogia recobre relaçóes diversas, que poderíamos chamar de deslocamento ou de inversáo. O primeiro termo caracterizava, em uma nova referência a Freud, um deslocamento de afeto: Kostia se dá conta, sem nem mesmo saber por que, de que é mais capaz de mostrar os sentimentos experimentados diante de um macaco
} 
apenas uma e vaga definição: "Existe entre o estimulante e o sentimento uma ligação natural e normal”. Essa ligação deve ser suscitada artificialmente: "Nossas emoções artísticas se escondem nas profundezas do nosso ser, como bestas selvagens. Se elas não vêm por si mesmas à superfície, será impossível para você fazê-las sair de seu esconderijo. Você precisará achar uma armadilha, uma 'isca' qualquer para atraí-las”.* Ou seja, um método de dramatização.

Dentre outras cenas e mais do que outras, a cena do dinheiro queimado atesta a necessidade de o ator procurar as formas, os sentimentos e as açóes que lhe permitirão viver e reviver uma prova e fazê-la viver, ou reviver igualmente, para o público. É precisamente porque ela é, de acordo com a concepção de Stanislavski, um episódio crítico e fundador da experiência do ator que age como um episódio crítico e fundador da "encenação".

Esse retorno à experiência ou essa retomada da experiência, para retomar o termo de Jean-Pierre Sarrazac, ${ }^{*}$ coloca duas condiçóes: esgotar o melodrama e autonomizar a cena. Esse retorno implica dois movimentos. Pela contestação da forma, pelo trabalho do ator sobre si mesmo, ele se inscreve na ética e na estética do trabalho da arte sobre si mesma, próprio do que se pode chamar de modernidade artística. Pela sacralização do espaço, ele radicaliza a dissolução, ainda hoje muito moderna, do autor em sua obra, aqui, do ator em seu papel ou, para parafrasear um outro título de Stanislavski, de sua vida em sua arte. ${ }^{5}$ Por colocar em risco o excesso, ele se propóe liberar, como tantos esboços, os gestos e as imagens para, em seguida, adaptá-los aos excessos próprios à poesia da linguagem.

morto do que o horror sentido quando do acidente de um velho esmagado por um bonde (STANISLAVSKI, Constantin. La formation de l'acteur, op. cit.: 173175). A inversão mostra que se pode utilizar uma experiência passiva da vida para criar uma experiência ativa no palco: eu vi alguém levar um tapa e interpreto aquele que leva o tapa. É o que Stanislavski chama de "passagem da simpatia para o sentimento", e que poderíamos chamar ainda de transformação do testemunho em ação (Ibidem: 190-191). Em um caso ou no outro, a regra da analogia, a analogia como regra permite não "se distanciar de si mesmo" (Ibidem: 180). Faltaria definir o critério da distância: questão que lembra, ou chama, a comparação da criação teatral com a criação poética.

${ }^{5} \mathrm{O}$ que autorizará também linhas como as de Grotowski ou de Barba, nas quais se trata de formar tanto um indivíduo quanto um ator.
* (Ibidem: 192.)

* (Cf. SARRAZAC, JeanPierre, "La reprise (réponse au postdramatique)". In: Études théâtrales, n³8-39, "La réinvention du drame (sous l'influence de la scène)", sob a direção de Jean-Pierre Sarrazac e Catherine Naugrette, 2007: 7-18.) 
Ler, assim, um método de encenação, paralelamente, com a reflexão de um escritor no limite entre memória, crítica, poesia e filosofia, mostra a que ponto a impermeabilidade muito frequente entre a letra e o palco é superável para tecer relaçóes proveitosas, para a leitura do teatro e para a ampliação do campo de ação da escrita. Nesse contexto, vê-se aqui o quanto a abordagem de Stanislavski é a de um escritor da cena, e o quanto não é à toa que Bataille maneja a metáfora teatral.

Tradução de Daniel Teixeira da Costa Araújo (Doutorando em Literaturas de Lingua Francesal UFRJ)

Christophe Bident é professor de teatro na Universidade de Picardie Jules Verne (Amiens), onde dirige a UFR de Arte. É autor de Maurice Blanchot, partenaire invisible (Champ Vallon, 1998), Bernard-Marie Koltès, Généalogies (Farrago, 2000), Reconnaissances - Antelme, Blanchot, Deleuze (Calmann-Lévy, 2003) e de Geste théatral de Roland Barthes (Hermann, 2012). Seu trabalho se situa na confluência entre a literatura, o teatro e a filosofia. E-mail: <christophe.bident@orange.fr>. 